\title{
Potential Benefits of Probiotics for Preterm Infants: A Review
}

\author{
S. Sarkar
}

\author{
Metro Dairy Limited, Barrackpore-Barasat Link Road, Subhasnagar, P.O. Neelgunj Bazar, Kolkata-700121, \\ West Bengal, India
}

\begin{abstract}
Preterm infants are particularly susceptible to abnormal colonization and are therefore prone to systemic infections due to increased intestinal permeability to potentially pathogens. Abnormal pattern of colonization in pre-term infants may contribute to the pathogenesis of neonatal Necrotizing Enterocolitis (NEC), an acquired gastrointestinal (GI) disease associated with significant morbidity and mortality. Introduction of foods containing probiotic cultures may be advantageous as probiotics prevented gut colonization by abnormal flora. Endeavour has been made to explore the mechanism of gut colonization, suitability of breast milk for preterm infants, effect of administration of probiotics to preterm infants and its safety concerns. Human milk is also suitable for the management of premature infants but fortified breast milk may be a preferred choice and not the pooled pasteurized breast milk. Based upon Randomized Controlled Trials administration of probiotic in preterm infants with a birth weight $>1000 \mathrm{~g}$ could be recommended due to significantly reduction in incidence of NEC and no systemic infections or serious adverse events was reported. Administration of probiotics in preterm neonates is recommended but further research is emerging for its routine application. Probiotic supplementation in preterm neonates exhibited good safety profile and did not show any side effects and can be recommended for preterm infants but not for extremely low birth weight (ELBW) infants [1, 2].
\end{abstract}

Keywords: Probiotics, Preterm infants, Breast milk, Gut colonization.

\section{INTRODUCTION}

Human breast milk is the best preferred choice for infant nutrition [3] owing to its inherent therapeutic and nutritional features $[4,5]$ and breastfeeding during the first 6 months of life for both normal and premature infants have been recommended [6,7]. NEC is a medical condition primarily seen in premature infants where portion of bowel undergoes necrosis (tissue death). Premature infants could be categorized into three groups on the basis of birth weight as ELBW (< $1000 \mathrm{~g})$, very low birth weight $(<1500 \mathrm{~g})$ and low birth weight $(<2500 \mathrm{~g})$. Premature infants are at greater risk than full-term infants due to delayed and abnormal pattern of gut colonization [8, 9, 10] which may predispose them to NEC $[11,12]$ and increase the risk of bacterial translocation [13]. No colonization by probiotic strains was detected in infants who weighed $\leq 1000 \mathrm{~g}$, presumably because of more frequent suspensions of enteral feeding, more courses of antibiotic treatment, or both [14]. Based upon current evidence $L$. reuteri DSM 17938 is not recommended for infant feeding as it failed prevent NEC [15].

Human milk is also suitable for the management of premature infants (AAP, 1997) but fortified breast milk may be a preferred choice [16] and not the pooled pasteurized breast milk [17]. Recently, clinical studies proposed inclusion of certain immuno-regulatory substances such as nucleotides, prebiotics or

*Address correspondence to this author at the Metro Dairy Limited, Barrackpore-Barasat Link Road, Subhasnagar, P.O. Neelgunj Bazar, Kolkata700121, West Bengal, India; Tel: 91-3325425381; Fax: 91-33254425385; E-mail: drsurajitsarkar@yahoo.co.in probiotics to the nutrition of infants to enhance the bifidogenic effect on the gut flora, thereby reducing the number of latent invasive bacteria $[18,19]$. Under these circumstances various specially developed cultured milk products can be recommended for feeding both normal and sick infants [20] and health promising results due to probiotic supplementation in low birth weight infants are reported [21, 22]. Probiotics are living microorganisms in foodstuffs which when ingested at certain levels provide equilibrium of the intestinal flora thus exhibiting a positive effect of consumer's health [23]. A double-blind, randomized controlled trial revealed that probiotic supplementation was efficacious in full-term infants with critical illness and induced a significantly reduced rate of nosocomial pneumonia (18\% vs. $36 \%)$ and multiple organ dysfunction syndrome ( $6 \%$ vs. $16 \%$ ) compared with the placebo group [24]. In the present article an endeavor has been made to enlighten suitability of probiotic supplementation for preterm infants in absence of human milk.

\section{COLONIZATION OF GUT FLORA OF PREMATURE INFANTS}

Human GI tract is sterile immediately after birth and is colonized by vaginal and faecal flora of mothers during birth $[25,26]$. Microbes have also been detected in amniotic fluid and placenta from mothers and in the umbilical cord blood of healthy neonates [27] suggesting their contribution towards the initial colonization of the neonatal gut. Intestinal microbiota of mother during pregnancy is important as mother-fetal interactions influence the infant's health later in life. 
Transfer of maternal features to the newborn and intestinal microbiota of normal-weight pregnant women to be more populated with Bifidobacterium and Bacteroides and less with Staphylococcus, Enterobacteriaceae, and Escherichia coli in contrast to overweight pregnant women were noted [28] . Higher incidence of $E$. coli in feaces of women with excessive weight gain with respect to those with normal weight gain was also reported by them. The most important determinants of the gut microbiotic composition in infants were the mode of delivery, type of infant feeding, gestational age, infant hospitalization, and antibiotic use by the infant. The newborn gut microflora foster integrity of the immune system protecting from infections with enteric pathogens, produce vitamins, and encourage mucosal maturation [29, 30].

Dominance of bifidobacteria and other lactic acid bacteria in breast-fed infants but a more diverse microbial population comprising of bifidobacteria, Bacteroides, Clostridia and streptococci, staphylococci, streptococci and Enterobacteriaceae in formula-fed infants have been reported [31, 32]. Preterm infants are particularly susceptible to abnormal colonization. Diversity in gut flora of preterm infants and term infants $[8,33]$ and delayed bifidobacteria colonization [8] coupled with higher prevalence of Clostridium difficile [34] in preterm infants may be attributable to the use of parenteral nutrition and antibiotic therapy for extended periods [8]. Gut colonization in breast-fed preterm infants was characterized by high initial numbers of enterobacteria and streptococci, while bifidobacteria appeared on 11 day and became predominant on 19 day, in contrast to full-term infants who were colonized at 4 days of age [8].

Various factors such as the immature intestinal function, frequent use of broad-spectrum antibiotics, delay in initiating enteral feeding, infection control procedures and sterilization of milk limit the exposure of preterm infants to normal commensal microorganisms [14] and are therefore prone to systemic infections due to increased intestinal permeability to potentially pathogens [35]. Low-birthweight premature infants delivered by caesarian section are more prone to microbial infections due to late initiation of breast feeding, no colonization as resulted from ingestion during vaginal birth [36] and antibiotic therapy [34]. Antibiotic administration results in suppression of all anaerobic bacteria except clostridia and increased numbers of Klebsiella, Enterobacter, Citrobacter and Pseudomonas and Lactobacilli and bifidobacteria are generally absent in the intestine of antibiotic-treated infants [37, 38]. Fecal flora of a pre-term infant's intestine constituted of less than 20 different bacterial strains [36], whereas these of healthy adults had more than 400 types [39]. Stool specimens of extremely low birth-weight $(<1000 \mathrm{~g})$ infants were predominated with Enterococcus faecalis, Escherichia coli, Staphylococcus epidermidis, Enterobacter cloacae, Klebsiella pneumoniae, Staphylococcus haemolyticus, however Lactobacillus and bifidobacteria spp. could be identified in only one stool specimens [36].

Premature newborns in the intensive care acquire colonizing bacteria from the intensive care microenvironment rather than their mother [9] and harbor a bacterial flora composed of predominant aerobes such as Staphylococcus aureus, Klebsiella and enterococci, whereas the predominant anaerobes include Clostridia [36]. All preterm infants attain more similar genetic profiles in fecal samples after four weeks, indicating that all preterm infants had a similar bacterial composition, regardless of birth weight, feeding regime, and antibiotic therapy [9].

Various pathways for early patterns of microbial colonization are enumerated below [40].

- enhancement of the mucosal protective barrier

- modification of systemic immune response

- competitive exclusion of less desirable microbe

- $\quad$ protein and carbohydrate degradation

- vitamin and butyrate production

- mucosal differentiation

Preterm infants have immature physiological systems due to an underdeveloped Gl resulting in translocation of potentially pathogenic bacteria from the intestinal lumen causing systemic infections [41, 42]. Factors influencing the onset of infections in preterm infants are depicted below [43].

- $\quad$ origin of infections before birth

- $\quad$ intrauterine (prenatal) onset of infections

- poor development of splanchnic organs of the newborn

- immature Gl tract

- $\quad$ origin of infections because of NICU (Neonatal intensive care unit) environment

- invasive NICU care including mechanical ventilation 
- $\quad$ misuse of intravenous antibiotics at the NICU

- $\quad$ total parenteral nutrition using indwelling lines

- $\quad$ origin of infections related to the GI tract

- $\quad$ early/late onset of enteral feeding?

- $\quad$ amount of nutrition (minimal enteral nutrition)

- relation to the origin of NEC

- $\quad$ postnatal malnutrition particularly in infants, 26 weeks

- $\quad$ effects on infections by specific food components

- $\quad$ effects of amino acids, nucleotides, pre- and probiotics

The ability of non pathogenic intestinal microflora, such as lactic acid bacteria, to associate with and bind to the intestinal brush border tissue is thought to be an important attribute that prevents harmful pathogens from accessing the GI mucosa [44]. Abnormal pattern of colonization in pre-term infants may contribute to the pathogenesis of neonatal NEC, an acquired GI disease associated with significant morbidity and mortality. [11, 12] and increase the risk of bacterial translocation [13]. Initially, ischaemic injury to the immature gastrointestinal tract (GIT) was thought to be the basic cause of NEC, later other involved factors such as issues related to the introduction and advancement of enteric feeding, alterations in the normal bacterial colonization of the GIT, bacterial translocation and activation of the cytokine cascade, decreased epidermal growth factor, increased platelet activating factor and mucosal damage from free radical production were reported [45].

\section{BREAST MILK FOR PREMATURE INFANTS}

Breastfeeding confers advantages on both mothers and babies, including health, immunological, developmental, psychological, social, economic and environmental benefits [46]. Human milk is suitable for the management of premature infants [47] due to certain benefits such as improvements in host defense, digestion and absorption of nutrients, neurodevelopment, GI function as well as psychological effects on the mother [48]. Trophic feeds, defined as minimal volumes of milk feeds $(10-15 \mathrm{~mL} / \mathrm{kg} /$ day) should be started within $24 \mathrm{~h}$ of life [49]. Premature infants must be offered more human milk to lower the incidence of NEC and shorter duration of hospitalization [16, 50]. Mother's own milk should be the first choice for feeding preterm infants but in case of insufficient production, donor human milk should be preferred [51] over a preterm formula for retaining the protective effects of mother's milk [50]. One of the studies revealed donor breast milk to be equally efficacious as mother's own milk towards protection against NEC [52], however, meta-analysis of published data indicated poor growth in infants receiving donor milk compared to those receiving preterm formula [50, $53,54]$. Protective effect of donor milk for NEC is not conclusive. Optimizing of the banking procedure and application of breast milk fortifiers are suggested to overcome the losses of biological components due to storage and pasteurization of donor milk [51]. In case of unavailability of maternal or donor milk, formula milk should be introduced within 24-48 h [49].

Concentrations of protein, sodium and zinc decline in human milk with the continuation of lactation, but the nutrient needs of VLBW infants remain high [55] and therefore exclusive feeding of premature infants with unfortified human milk may be associated with poor rates of growth and nutritional deficits during and beyond the period of hospitalization $[56,57]$ and must be supplemented with necessary nutrients to optimize it for feeding premature infants $[58,59]$. Introduction of reformulated iron-fortified powdered human milk fortifier and powdered commercially available human milk fortifier were reported to be safe and lower incidence for NEC and sepsis encountered in VLBW infants than those fed with human milk [60]. Premature human milk has strong antimicrobial activity against Escherichia coli, Staphylococcus aureus, Pseudomonas aeruginosa and Candida albicans and addition of the milk fortifier Eoprotein does not change this effect, however the antimicrobial activity reduced with the addition of iron [61]. It was suggest that despite a slower early growth rate, human milk fed low birth weight infants have development at least comparable to that of infants fed nutrient-enriched formula [62].

\section{PROBIOTICS FOR PREMATURE INFANTS}

Probiotic bacteria are reported not only to compete and suppress 'unhealthy fermentation' in human intestine but also to exhibit a number of beneficial health effects [63] either directly or indirectly through modulation of the endogenous ecosystem or immune system [64], competitive interactions, direct antagonism of pathogens, and production of antimicrobial factors [65]. Recommended probiotic cultures for preterm infants are enlisted in Table 1.

Probiotics prevented gut colonization by Candida and conferred protection against sepis and abnormal 
Table 1: Recommended Probiotic Cultures for Preterm Infants

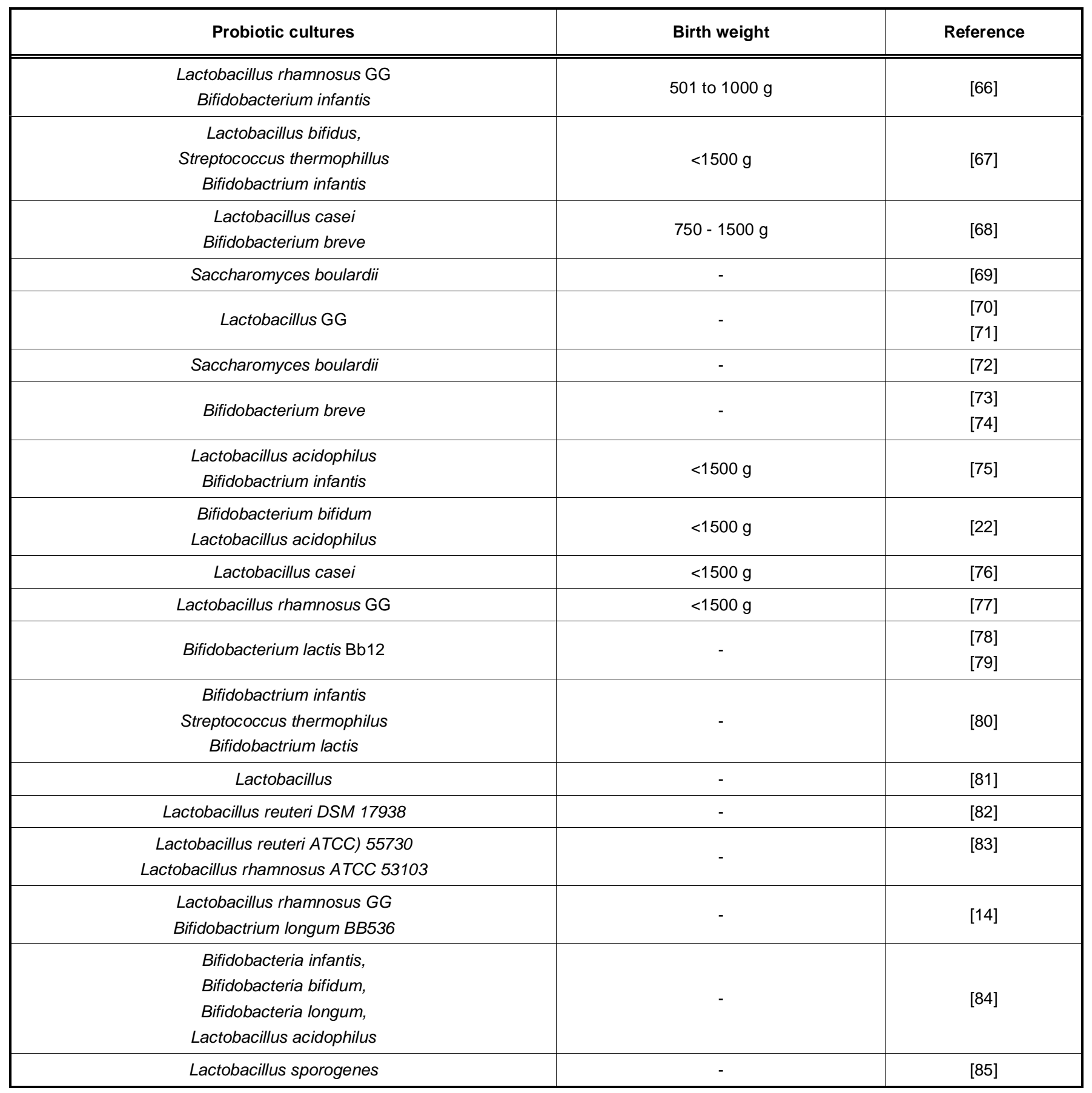

neurological outcomes in preterm infants and greater efficacy of $L$. reuteri than $L$. rhamnosus [83] may be attributed to a lower colonization of $L$. rhamnosus in preterm infants with a birth weight $<1500 \mathrm{~g}$ than in those with a birth weight between 1500 and $1999 \mathrm{~g}$ [86]. Administration of Lactobacillus acidophilus at a level of $10^{8} \mathrm{cfu}$ induced colonization of GIT with Lactobacillus in $37 \%$ preterm infants and improved feeding tolerance [87].
Reviewed literature provided evidence-based guidelines which indicated that Lactobacillus GG alone may not be effective but a probiotic combination comprising of Lactobacillus and at least one Bifidobacterium species at a daily dose level of $3 \times 10^{9}$ organisms must be initiated within first 7 days of life and to be continued for at least until 35 weeks corrected age or discharge in preterm neonates [67, 75]. Supplementation with Bifidobacterium longum BB536 and Lactobacillus rhamnosus GG may not 
improve the GI tolerance to enteral feeding in very-lowbirth weight infants but may improve Gl tolerance in infants weighing $>1000$ g. [14]. Onset of bacterial resistance against antibiotics is suspected [40] but a reduction in the incidence of death or NEC in very low birth weight preterm infants was encountered due to administration of Bifidobacterium and Lactobacillus for 6 weeks [22].

Based upon Randomized Controlled Trials (RCT) administration of probiotic in preterm infants with a birth weight $>1000 \mathrm{~g}$ could be recommended due to significantly reduction in incidence of NEC $[21,88$. 89] and no systemic infections or serious adverse events was reported. Recently systematic reviews of randomized, controlled trials indicated lower mortality and NEC in very low birth weight neonates [90]. Enteral feeding of premature infants with Lactobacillus sp. strain GG showed survival of the organism through the GIT but could not confer any detectable benefits [70]. Probiotic supplementation induced colonization of intestinal flora with Bifidobacterium lactis Bb12 [78] in preterm infants and resulted in beneficial effects on survival, infection rate, and incidence of NEC [75] and a recent double-blind, randomized, controlled clinical trial concluded that oral probiotic supplementation with $B$. breve and $L$. casei reduced the occurrence of NEC [68]. Probiotic supplementation comprising Bifidobacterium infantis, Lactobacillus, and B. lactis to preterm modulated the intestinal microflora and minimize enteral fungal colonization, reduced invasive fungal sepsis, earlier establishment of full enteral feeds, and reduced duration of hospital [91]. A joint $\mathrm{FAO} / \mathrm{WHO}$ report stated that $B$. lactis is the only probiotic bacterium which has undergone FDA evaluation for use in infant formulas from birth and has been found equally safe for vulnerable populations, such as preterm infants, malnourished infants that can be commercialized for this application [92].

Protective effect of probiotics towards development of NEC and/or sepsis in high risk infants may be attributed to increased barrier for migration of bacteria and their products across the mucosa [93, 94], competitive exclusion of potential pathogens [95], modification of host response to microbial products [96], augmentation of IGA mucosal responses, enhancement of enteral nutrition that inhibit the growth of pathogens and up-regulation of immune responses [97]. Probiotics may play a role in preventing the onset of NEC $[45,98]$ however more large-scale, definitive studies [45] and understanding of the mechanisms of the microbiota-epithelium interactions through parallel infant and animal trials [99] are emerging. Inconsistent effect of probiotic administration on NEC sensitivity in preterm pigs (decreases and increases) but decreased NEC incidence in preterm infants indicate host defense factors appear more important than the nature of the gut microbiota [100]. Probiotics found efficacious in the prevention of NEC in certain populations of preterm infants but further research are required to explore appropriate treatment regimes, strain-specific effects on sub-selected populations and long term effects of probiotic administration [100]. Administration of probiotics in preterm neonates is recommended but further research are emerging for its routine application [101], countries such as Denmark have already issued guidelines for use of probiotics in preterm neonates [102].

\section{SAFETY OF PROBIOTIC APPLICATIONS IN PRE- MATURE INFANTS}

Administration of probiotics during the perinatal and early postnatal period [103] and lactation favour infant gut colonization due to transmission of beneficial microflora from mother to neonate through direct contact with maternal microbiota during birth and through the supply of breast-milk bacteria during lactation $[103,105]$.

Although probiotics have an excellent overall safety record but may not be appropriate for premature neonates and generalized statement for prophylactic properties of probiotics should not be given as it is strain specific [106]. Routine use of probiotics in the preterm infant could not be recommended due to many uncertainties such as the mechanisms of action of probiotics, health effects of employed probiotics, determination of reasons for the efficacy of probiotics, forms of microbial adaptations and ecological consequences [107]. Probiotics may differ in their efficacy to exhibit health benefits and all probiotics have been studied therefore general recommendations for all probiotics cannot be made [21]. Routine probiotic supplementation is justified for preterm infants except for ELBW [1, 2] and further investigations are required to assess the potential benefit and safety of probiotic supplementation for ELBW infants [21, 108]. Probiotic supplementation in preterm neonates exhibited good safety profile and did not show any side effects [91], however more randomized controlled trials to evaluate safety profile of probiotic supplementation for the prevention of NEC in ELBW infants [109] and as an additive treatment to prevent invasive fungal infections in preterm neonates [91] are emerging. Further, optimal 
probiotic strain, duration of administration and host selectivity remain unclear due to heterogeneity of trial design and therefore repeated studies using a single design protocol to demonstrate reproducibility, safety and efficacy are suggested [110]. Reviews on clinical report on the use of probiotics indicated modestly effectiveness in treating acute viral gastroenteritis and preventing antibiotic-associated diarrhea but preliminary encouraging results for the treatment childhood Helicobacter pylori gastritis, irritable bowel syndrome, chronic ulcerative colitis and infantile colic in healthy children and require further confirmation [107].

\section{CONCLUSION}

Preterm infants are prone to systemic infections due to increased intestinal permeability to potentially pathogens resulting from immature intestinal function, frequent use of broad-spectrum antibiotics, delay in initiating enteral feeding, infection control procedures and sterilization of milk. Abnormal pattern of colonization in pre-term infants may contribute to the pathogenesis of neonatal NEC, an acquired GI disease associated with significant morbidity and mortality. Introduction of foods containing probiotic cultures may be advantageous as probiotics prevented gut colonization. Probiotic supplementation in preterm neonates exhibited good safety profile and did not show any side effects and can be recommended for preterm infants but not for ELBW infants.

\section{REFERENCES}

[1] Deshpande G, Rao S and Patole S. Probiotics for prevention of necrotizing enterocolitis in preterm neonates with very low birthweight: a systematic review of randomised controlled trials. Year book of Pediatrics, Ed. Newborn Stockman, JA, Elsevier Mosb, 2009; pp. 441-43.

[2] Indrio F, Riezzo G, Raimond F, Bisceglia M, Cavallo L and Francavilla $R$. The effects of probiotics on feeding tolerance, bowel habits, and gastrointestinal motility in preterm newborns. Year book of Neonatal and Perinatal Medicine Gastroenterology and Nutrition, Chapter 14, Ed: Fanaroff AA, Benitz W, Neu J and Papille L, Elsevier Mosby, 2009, pp.138-39.

[3] Cuthbertson WJF. Evolution of infant nutrition. Br J Nutr 1999; 81: 359-71.

[4] Sarkar S. Therapeutic aspects of breast milk. Nutr Fd Sci 2004; 34: 108-12. http://dx.doi.org/10.1108/00346650410536719

[5] Sarkar S. Nutritional aspects of breast milk. Nutr Fd Sci 2004; 34: 151-55. http://dx.doi.org/10.1108/00346650410544837

[6] WHO Global strategy for infant and young child feeding. The optimal duration of exclusive breastfeeding, Fifty-Fourth World Health Assembly, 2001, Geneva, Switzerland.

[7] AAP. Section on breastfeeding, Breastfeeding and the use of human milk. American Academy of Pediatrics. Pediat 2005; 115: 496-506.

http://dx.doi.org/10.1542/peds.2004-2491
Sakata H, Yoshioka, H and Fujita K. Development of the intestinal flora in very low birth weight infants compared to normal full-term newborns. Eur J Pediatr 1985; 144: 186-90. http://dx.doi.org/10.1007/BF00451911

[9] Schwiertz A, Gruhl B, Lobnitz M, Michel P, Radke M and Blaut M. Development of the intestinal bacterial composition in hospitalised preterm infants in comparison with breast-fed, full-term infants. Pediatr Res 2003; 54: 393-99. http://dx.doi.org/10.1203/01.PDR.0000078274.74607.7A

[10] Butel MJ, Suau A, Campeotto F, Magne F, Aires J, Ferraris L, Kalach N, Leroux B and Dupont C. Conditions of bifidobacterial colonization in preterm infants: a prospective analysis. J Pediat Gastroenterol Nutr 2007; 44: 577-82. http://dx.doi.org/10.1097/MPG.0b013e3180406b20

[11] Butel MJ, Roland N, Hibert A, Popot F, Favre A, Tessèdre $A C$, Bensaada $M$, Rimbault $A$ and Szylit $O$. Clostridial pathogenicity in experimental necrotising enterocolitis in gnotobiotic quails and protective role of bifidobacteria. $\mathrm{J}$ Med Microbiol 1998; 47: 391-99. http://dx.doi.org/10.1099/00222615-47-5-391

[12] Claud EC and Walker WA. Hypothesis: inappropriate colonisation of thepremature intestine can cause neonatal necrotizing enterocolitis. FASEB J 2001; 15: 1398-403.

http://dx.doi.org/10.1096/fj.00-0833hyp

[13] Dai D and Walker WA. Protective nutrients and bacterial colonization in the immature human gut. Adv Pediatr 1999; 46: 353-82.

[14] Rouge C, Piloquet H, Butel MJ, Berger B, Rochat F, Ferraris L, Robert CD, Legrand A, de la Cochetie're MF, N'Guyen JM, Vodovar M, Voyer M, e Darmaun D and Roze JC. Oral supplementation with probiotics in very-low-birth-weight preterm infants: a randomized, double-blind, placebocontrolled trial. Am J Clin Nutr 2009; 89: 1828-35. http://dx.doi.org/10.3945/ajcn.2008.26919

[15] Urbańska M and Szajewska H. The efficacy of Lactobacillus reuteri DSM 17938 in infants and children: a review of the current evidence. Eur J Pediatr 2014; 173: 1327-37. http://dx.doi.org/10.1007/s00431-014-2328-0

[16] Schanler RJ, Shulman RJ and Lau C. Feeding strategies for premature infants: beneficial outcomes of feeding fortified human milk versus preterm formula. Pediatr 1999; 103: 1150-57.

http://dx.doi.org/10.1542/peds.103.6.1150

[17] Stein H, Cohen D, Herman AA, Rissik J, Ellis U, Bolton K, Pettifor $\mathrm{J}$ and MacDougall L. Pooled pasteurized breast milk and untreated own mother's milk in the feeding of very low birth weight babies: a randomized controlled trial. J Pediat Gastroenterol Nutr 1986; 5: 242-47.

http://dx.doi.org/10.1097/00005176-198605020-00014

[18] Moro G, Minoli I, Mosca M, Fanaro S, Jelinek J, Stahl B and Boehm G. Dosage-related bifidogenic effects of galacto and fructooligosaccharides in formula-fed term infants. J Pediat Gastroenterol Nutr 2002; 34: 291-95.

http://dx.doi.org/10.1097/00005176-200203000-00014

[19] Boehm G, Lidestri M, Casetta P, Jelinek J, Negretti F, Stahl $B$ and Marini A. Supplementation of a bovine milk formula with an oligosaccharide mixture increases counts of fecal bifidobacteria in preterm infants. Arch Dis Child Fetal Neonatal Edu 2002; 86: 178-81.

http://dx.doi.org/10.1136/fn.86.3.F178

[20] Sarkar S. Recent innovations in cultured milk products for infants. Nutr Fd Sci 2003; 33: 268-72.

http://dx.doi.org/10.1108/00346650310507091

[21] Alfaleh $K$ and Bassler D. Probiotics for prevention of necrotizing enterocolitis in preterm infants. Cochrane Database Syst Rev 2008; No.1, CD005496.

http://dx.doi.org/10.1002/14651858.cd005496.pub2

[22] Lin HC, Hsu CH, Chen HL, Chung MY, Hsu JF, Lien RI, Tsao $\mathrm{LY}$, Chen $\mathrm{CH}$ and $\mathrm{Su} \mathrm{BH}$. Oral probiotics prevent necrotizing enterocolitis in very low birth weight preterm infants: a 
multicenter, randomized, controlled trial. Pediat 2008; 122: 693-700.

http://dx.doi.org/10.1542/peds.2007-3007

[23] Tomasik PJ and Tomasik P. Probiotics and prebiotics. Am Assoc Cereal Chemists 2003; 80: 113-37.

http://dx.doi.org/10.1094/CCHEM.2003.80.2.113

[24] Wang Y, Gao, L, Zhang, YH, Shi, CS and Ren, CM. Probiotic therapy was reported to be efficacious in full-term infants with critical illness.Asia Pac J Clin Nutr 2014; 23: 575-80.

[25] Bennet R and Nord CE. Development of the fecal anaerobic microflora after cesarean section and treatment with antibiotics in newborn infants. Infection 1987; 15: 332-36. http://dx.doi.org/10.1007/BF01647733

[26] Favier CF, Vaughan EE, Devos WM and Akkermans ADL. Molecular monitoring of succession of bacterial communities in human neonates. Appl Envir Microbiol 2002; 68: 219-26. http://dx.doi.org/10.1128/AEM.68.1.219-226.2002

[27] Pettker CM, Buhimschi IA, Magloire LK, Sfakianaki AK, Hamar BD and Buhimschi CS. Value of placental microbial evaluation in diagnosing intra-amniotic infection. Obstet Gynecol 2007; 109: 739-49.

http://dx.doi.org/10.1097/01.AOG.0000255663.47512.23

[28] Santacruza A, Colladoa MC, García-Valdesa L, Seguraa MT, Martín-Lagosa JA, Anjosa T, Martí-Romeroa M, Lopeza RM, Floridoa J, Campoya C and Sanza Y. Gut microbiota composition is associated with body weight, weight gain and biochemical parameters in pregnant women. Br J Nutr. 2010; 104: 83-92.

http://dx.doi.org/10.1017/S0007114510000176

[29] Pietzak M. Bacterial colonization of the neonatal gut. J Pediatr Gastroenterol Nutr 2004; 38: 389-91. http://dx.doi.org/10.1097/00005176-200404000-00005

[30] Magne F, Suau A, Pochart $P$ and Desjeux JF. Fecal microbial community in preterm infants. J Pediat Gastroenterol Nutr 2005; 41: 386-92. http://dx.doi.org/10.1097/01.mpg.0000179855.38543.85

[31] Rubaltelli FF, Biadaioli $R$, Pecile $P$ and Nicoletti $P$. Intestinal flora in breast- and bottle-fed infants. J Perinat Med 1998; 26: $186-91$.

http://dx.doi.org/10.1515/ipme.1998.26.3.186

[32] Harmsen HJM, Wildeboer-Veloo ACM, Raangs GC, Wagendorp AA, Klijn N, Bindels JG and Welling GW. Analysis of intestinal flora development in breast-fed and formulafed infants by using molecular identification and detection methods. J Pediat Gastroenterol Nutr 2000; 30: 61-67. http://dx.doi.org/10.1097/00005176-200001000-00019

[33] Bennet R, Eriksson M, Nord CE and Zetterstrom R. Fecal bacterial microflora of newborn infants during intensive care management and treatment with five antibiotic regimens. Pediatr Infect Dis 1986; 5: 533-39.

http://dx.doi.org/10.1097/00006454-198609000-00009

[34] Penders J, Thijs C, Vink, C, Stelma FF, Snijders B, Kummeling $I$, van den Brandt $P A$ and Stobberingh EE. Factors influencing the composition of the intestinal microbiota in early infancy. Pediatr 2006; 118: 511-21. http://dx.doi.org/10.1542/peds.2005-2824

[35] Westerbeek EAM, van den Berg A, Lafeber HN, Knol J, Fetter WPF, and van Elburg, RM. The intestinal bacterial colonisation in preterm infants: A review of the literature. Clin Nutr 2006; 25: 361-68.

http://dx.doi.org/10.1016/j.clnu.2006.03.002

[36] Gewold IH, Schwalbe RS, Taciak VL, Harrisonn TS and Panigrahi P. Stool microflora in extremely low birth weight infants. Arch Dis Child Fetal Neonatal Edu 1999; 80: 167-73. http://dx.doi.org/10.1136/fn.80.3.F167

[37] Hall MA, Cole CB, Smith SL, Fuller R and Rolles CJ. Factors influencing the presence of fecal lactobacilli in early infancy. Arch Dis Child 1990; 65: 185-88.

http://dx.doi.org/10.1136/adc.65.2.185
[38] Bennet R, Eriksson M and Nord CE. The fecal microfl ora of 1-3-month-old infants during treatment with eight oral antibiotics. Infection 2002; 30: 158-60. http://dx.doi.org/10.1007/s15010-002-2140-z

[39] Finegold SM, Sutter, VL and Mathisen GE. Normal indigenous intestinal flora. Human intestinal microflora in health and disease, Ed. Hentges, D.J., Academic Press, London, 1983, pp. 3. http://dx.doi.org/10.1016/B978-0-12-341280-5.50007-0

[40] Millar M, Wilks M and Costeloe K. Probiotics for preterm infants?. Arch Dis Child Fetal Neonatal Edu 2003; 88: 354-58. http://dx.doi.org/10.1136/fn.88.5.F354

[41] Lissauer $T$ and Fanaroff $A$. The preterm infant: growth and nutrition. Neonatology at a glance, Malden, Mass: Blackwell Publishing, 2006, pp. 76-77.

[42] Corpeleijin WE, van Vliet I, de Gast-Bakker DH, van der Schoor, SRD, Alles MS, Hoijer M, Tibboel D and van Goudoever JB. Effect of enteral IGF-1 supplementation on feeding tolerance, growth and gut permeability in enterally fed premature neonates. J Pediat Gastrotenterol Nutr 2008; 46: $184-90$.

http://dx.doi.org/10.1097/MPG.0b013e31815affec

[43] Lafeber HN, Westerbeek EA, van den Berg A, Fetter WP and van Elburg RM. Nutritional factors influencing infections in preterm infants. J Nutr 2008; 138: 1813-17.

[44] Bernet MF, Brassart D, Neeser JR and Servin AL. Lactobacillus acidophilus LA 1 binds to cultured human intestinal cell lines and inhibits cell attachment and cell invasion by enterovirulent bacteria. Gut 1994; 35: 483-89. http://dx.doi.org/10.1136/gut.35.4.483

[45] Thompson AM and Bizzarro MJ. Necrotizing enterocolitis in newborns: Pathogenesis, prevention and management. Drugs 2008; 68: 1227-38.

http://dx.doi.org/10.2165/00003495-200868090-00004

[46] Gartner LM, Morton J, Lawrence RA, Naylor AJ, O'Hare D, Schanler, RJ and Eidelman Al. Breastfeeding and the use of human milk. Pediat 2005; 115: 496-506. http://dx.doi.org/10.1542/peds.2004-2491

[47] AAP. Breastfeeding and the use of human milk. American Academy of Pediatrics, Work Group on Breastfeeding, Pediat 1997; 100: 1035-39. http://dx.doi.org/10.1542/peds.100.6.1035

[48] Schanler RJ. Suitability of human milk for the low birth weight infant. Clin Perinatol 1995; 22: 207-22.

[49] Dutta S, Singh B, Chessell L, Wilson J, Janes M, McDonald K, Shahid S, Gardner VA, Hjartarson A, Purcha M, Watson J, de Boer C, Gaal B and Fusch C. Guidelines for feeding very low birth weight infants. Nutr 2015; 7: 423-42. http://dx.doi.org/10.3390/nu7010423

[50] Schanler RJ, Lau C, Hurst NM and Smith EO. Randomized trial of donor human milk versus preterm formula as substitutes for mothers' own milk in the feeding of extremely premature infants. Pediatr 2005; 116: 400-406.

http://dx.doi.org/10.1542/peds.2004-1974

[51] Arslanoglu S, Ziegler EE, Moro, GE and the WAPM Working Group on Nutrition. Donor human milk in preterm infant feeding: evidence and recommendations. J Perinat Med 2010; 38: 347-51.

http://dx.doi.org/10.1515/jpm.2010.064

[52] Lucas A and Cole TJ. Breast milk and neonatal necrotising enterocolitis. Lancet 1990; 336: 1519-23. http://dx.doi.org/10.1016/0140-6736(90)93304-8

[53] McGuire W and Anthony MY. Donor human milk versus formula for preventing necrotizing enterocolitis in preterm infants: systematic review. Arch Dis Child Fetal Neonatal Edu 2003; 88: 11-14 http://dx.doi.org/10.1136/fn.88.1.F11

[54] Boyd CA, Quigley MA and Brocklehurst P. Donor breast milk versus infant formula for preterm infants: systematic review 
and meta-analysis. Arch Dis Child Fetal Neonatal Edu 2007; 92: 169-75.

http://dx.doi.org/10.1136/adc.2005.089490

[55] Ziegler EE. Breast-milk fortification. Acta Paediat 2001; 90: 720-23.

http://dx.doi.org/10.1080/08035250117346

[56] Kashyap S, Schulze KF, Forsyth M, Dell RB, Ramakrishnan $\mathrm{R}$ and Heird WC. Growth, nutrient retention, and metabolic response of low-birth-weight infants fed supplemented and unsupplemented preterm human milk. Am J Clin Nutr 1990; 52: $254-62$

[57] Contreras-Lemus J, Flores-Huerta S and Cisneros-Silva I. Decreased morbidity in preterm neonates fed their own mothers' milk. Biol Med Hosp Infant Mex 1992; 49: 671-77.

[58] Ronnholm KAR, Perheentupa $J$ and Siimes MA. Supplementation with human milk protein improves growth of small premature infants fed human milk. Pediatr 1986; 77: 649-53.

[59] Greer FR and McCormick A. Improved bone mineralization and growth in premature infants fed fortified own mother's milk. J Pediatr 1988; 112: 961-69.

http://dx.doi.org/10.1016/S0022-3476(88)80227-0

[60] Berseth CL, Van Aerde JE Gross S, Stolz SI, Harris CL and Hansen JW. Growth, efficacy, and safety of feeding an ironfortified human milk fortifier. Pediat; 2004 114: 699-706.

[61] Oval F, Ciftci H, Cetinkaya Z and Bukulmez A. Effects of human milk fortifier on the antimicrobial properties of human milk. J Perinatol 2006; 26: 761-63. http://dx.doi.org/10.1038/sj.jp.7211610

[62] O'Connor DL, Jacobs J, Hall R, Adamkin D, Auestad N, Castillo M, Connor WE, Connor SL, Fitzgerald K, GrohWargo S, Hartmann, EE, Janowsky J, Lucas A, Margeson D, Mena P, Neuringer M, Ross G, Singer L, Stephenson T, Szabo J and Zemon V. Growth and development of premature infants fed predominantly human milk, predominantly premature infant formula, or a combination of human milk and premature formula. J Pediatr Gastroenterol Nutr 2003; 37: 437-46.

http://dx.doi.org/10.1097/00005176-200310000-00008

[63] Fuller R. Probiotics in man and animals. J Appl Bacteriol 1989; 66: 365-78.

http://dx.doi.org/10.1111/j.1365-2672.1989.tb05105.x

[64] Marteau PR, de Vrese M, Cellier CJ and Schrezenmeir J. Protection from gastrointestinal diseases with the use of probiotics. Am J Clin Nutr 2001; 73: 430-36.

[65] Shanahan F. Probiotics: promise, problems, and progress. Gastroenterol. Hepatol Ann Rev 2006; 1: 41-45.

[66] Al-Hosni M, Duenas M, Hawk, M, Stewart, LA, Borghese, RA, Cahoon, M, Atwood, L, Howard, D, Ferrelli, K and Soll, R. Probiotics-supplemented feeding in extremely low-birthweight infants. J Perinatol 2012; 32: 253-59.

http://dx.doi.org/10.1038/jp.2011.51

[67] Bin-Nun A, Bromiker R, Wilschanski M, Kaplan M, Rudensky B, Caplan M and Hammerman C. Oral probiotics prevent necrotizing enterocolitis in very low birth weight neonates. $J$ Pediat 2005; 147: 192-96.

http://dx.doi.org/10.1016/i.jpeds.2005.03.054

[68] Braga DT, Pontes da Silva GA, Cabral de Lira PI and de Carvalho Lima M. Efficacy of Bifidobacterium breve and Lactobacillus casei oral supplementation on necrotizing enterocolitis in very-low-birth-weight preterm infants: a double-blind, randomized, controlled trial. Am J Clin Nutr 2011; 93: 81-86 http://dx.doi.org/10.3945/ajcn.2010.29799

[69] Costalos C, Skouteri V, Gounaris A, Sevastiadou S, Triandafilidou A, Ekonomidou C, Kontaxaki F and Petrochilou V. Enteral feeding of premature infants with Saccharomyces boulardii. Early Human Dev 2003; 74: 89-96.

http://dx.doi.org/10.1016/S0378-3782(03)00090-2
[70]

Millar MR, Bacon C, Smith SL, Walker V and Hall MA. Enteral feeding of premature infants with Lactobacillus GG. Arch Dis Childhood 1993; 69: 483-87. http://dx.doi.org/10.1136/adc.69.5 Spec No.483

[71] Dani C, Biadaioli R, Bertini G, Martelli E and Rubaltelli F. Probiotics feeding in prevention of urinary tract infection, bacterial sepsis and necrotizing enterocolitis in preterm infants. A prospective doubleblind study. Biol Neonate 2002; 82: $103-8$ http://dx.doi.org/10.1159/000063096

[72] Demirel $G$, Erdeve $O$, Celik $\mathrm{IH}$ and Dilmen $U$. Saccharomyces boulardii for prevention of necrotizing enterocolitis in preterm infants: a randomized, controlled study. Acta Paediat 2013; 102: 560-65. http://dx.doi.org/10.1111/apa.12416

[73] Kitajima $\mathrm{H}$, Sumida $\mathrm{Y}$, Tanaka R, Yuki TH and Fujimura M. Early administration of Bifidobacterium breve to preterm infants: randomised controlled trial. Arch Dis Childhood Fetal Neonat Edu 1997; 76: 101-107. http://dx.doi.org/10.1136/fn.76.2.F101

[74] Li Y, Shimizu T, Hosaka A, Kaneko N, Ohtsuka $Y$ and Yamashiro $Y$. Effects of Bifidobacterium breve supplementation on intestinal flora of low birth weight infants. Pediatr Int 2004; 46: 509-15. http://dx.doi.org/10.1111/j.1442-200x.2004.01953.x

[75] Lin HC, Su BH, Chen AC, Lin TW, Tsai CH, Yeh TF and Oh W. Oral probiotics reduce the incidence and severity of necrotizing enterocolitis in very low birth weight infants. Pediat 2005; 115: 1-4.

[76] Manzoni P, Mostert M, Leonessa ML, Priolo C, Farina D, Monetti C, Latino MA and Gomirato G. Oral supplementation with Lactobacillus casei subspecies rhamnosus prevents enteric colonization by Candida species in preterm neonates: A randomized study. Clin Infect Dis 2006; 15: 1735-42. http://dx.doi.org/10.1086/504324

[77] Manzoni P, Rinaldi M,, Cattani S, Pugni L, Romeo MG, Messner H, Stolfi I, Decembrino L, Laforgia N, Vagnarelli $F$, Memo L, Bordignon L, Saia OS, Maule M, Gallo E, Mostert MD, Magnani C, Quercia M, Bollani L, Pedicino R, Renzullo L, Betta, P, Mosca F, Ferrari F, Magaldi R, Stronati M and Farina D. Bovine lactoferrin supplementation for prevention of late-onset sepsis in very low-birth-weight neonates: A randomized trial. J Am Med Assoc 2009; 302: 1421-28. http://dx.doi.org/10.1001/jama.2009.1403

[78] Mohan R, Koebnick C, Schildt J, Schmidt S, Mueller M, Possner, M, Radke, $M$ and Blaut $M$. Effects of Bifidobacterium lactis $\mathrm{Bb} 12$ Supplementation on Intestinal Microbiota of Preterm Infants: a Double-Blind, PlaceboControlled, Randomized Study. J Clin Microbiol 2006; 44: 4025-31. http://dx.doi.org/10.1128/JCM.00767-06

[79] Mihatsch WA, Vossbeck S, Eikmanns B, Hoegel J and Pohlandt F. Effect of Bifidobacterium lactis on the incidence of nosocomial infections in very-low-birth-weight infants: a randomized controlled trial. Neonatol 2010; 98: 156-63. http://dx.doi.org/10.1159/000280291

[80] Jacobs SE, Tobin JM, Opie GF, Donath S, Tabrizi SN, Pirotta M, Morley CJ and Garland SM. Probiotic effects on late-onset sepsis in very preterm infants: A randomized controlled trial. Pediat 2013; 132: 1055-62. http://dx.doi.org/10.1542/peds.2013-1339

[81] Reuman PD, Duckworth DH, Smith KL, Kagan R, Bucciarelli $\mathrm{RL}$ and Ayoub EM. Lack of effect of Lactobacillus on gastrointestinal bacterial colonization in premature infants. Pediatric Infec Dis 1986; 5: 663-68. http://dx.doi.org/10.1097/00006454-198611000-00013

[82] Rojas MA, Lozano JM, Rojas MX, Rodriguez VA, Rondon MA, Bastidas JA, Perez LA, Rojas C, Ovalle O, GarciaHarker JE, Tamayo ME, Ruiz GC, Ballesteros A, Archila MM and Arevalo M. Prophylactic probiotics to prevent death and 
nosocomial infection in preterm infants. Pediatr 2012; 130, 5: 1113-20.

http://dx.doi.org/10.1542/peds.2011-3584

[83] Romeo MG, Romeo DM, Trovato L, Oliveri S, Palermo F, Cota $F$ and Betta $P$. Role of probiotics in the prevention of the enteric colonization by Candida in preterm newborns: incidence of late-onset sepsis and neurological outcome. J Perinatol 2011; 31: 63-69. http://dx.doi.org/10.1038/jp.2010.57

[84] Samanta M, Sarkar M, Ghosh P, Ghosh JK, Sinha MK and Chatterjee S. Prophylactic probiotics for prevention of necrotizing enterocolitis in very low birth weight new borns. J Trop Pediatr 2009; 55: 128-31. http://dx.doi.org/10.1093/tropej/fmn091

[85] Sari FN, Dizdar EA, Oguz S, Erdeve O, Uras N and Dilmen U. Oral probiotics: Lactobacillus sporogenes for prevention of necrotizing enterocolitis in very low-birth weight infants: a randomized, controlled trial. Europ J Clin Nutr 2011; 65: 43439.

http://dx.doi.org/10.1038/ejcn.2010.278

[86] Pappas PG, Rex JH, Sobel JD, Filler SD, Dismukes WE, Walsh TJ and Edwards JE. Guidelines for treatment of Candidiasis. Clin Infect Dis 2004; 38: 161-89.

http://dx.doi.org/10.1086/380796

[87] Lee SJ, Cho SJ and Park EA. Effects of probiotics on enteric flora and feeding tolerance in preterm infants. Neonatol 2007; 91: 174-79.

http://dx.doi.org/10.1159/000097449

[88] Deshpande G, Rao S and Patole S. Probiotics for prevention of necrotizing enterocolitis in preterm neonates with very low birthweight: a systematic review of randomised controlled trials.Lancet 2007; 369: 1614-20.

http://dx.doi.org/10.1016/S0140-6736(07)60748-X

[89] Barclay AR, Stenson B, Simpson JH, Weaver LT and Wilson DC. Probiotics for necrotizing enterocolitis: a systematic review. J Pediat Gastroenterol Nutr 2007; 45: 569-76. http://dx.doi.org/10.1097/MPG.0b013e3181344694

[90] Deshpande G, Rao S and Patole S and Bulsara M. Updated meta-analysis of probiotics for preventing necrotizing enterocolitis in preterm neonates. Pediat 2010; 125: 921-30. http://dx.doi.org/10.1542/peds.2009-1301

[91] Roy A Chaudhuri J, Sarkar D, Ghosh P and Chakraborty S. Role of Enteric Supplementation of Probiotics on Late-onset Sepsis by Candida species in Preterm Low Birth Weight Neonates: A Randomized, Double Blind, Placebo-controlled Trial. North Am J Med Sci 2014; 6: 50-57. http://dx.doi.org/10.4103/1947-2714.125870

[92] FAO/WHO. Guidelines for the Evaluation of Probiotics in Food", Working Group Report on Drafting Guidelines for the Evaluation of Probiotics in Food, London, Ontario, Canada, April 30 and May 1, 2002, Food and Agriculture Organization of the United nations World Health Organization, 2002, pp.111.

[93] Orrhage $\mathrm{K}$ and Nord CE. Factors controlling the bacterial colonization of the intestine in breastfed infants. Acta Paediatrica 1999; 88: 47-57.

http://dx.doi.org/10.1111/j.1651-2227.1999.tb01300.x

[94] Mattar AF, Drongowski RA, Coran AG and Harmon CM. Effect of probiotics on enterocyte bacterial translocation in vitro. Pediatric Sur Int 2001; 17: 265-68. http://dx.doi.org/10.1007/s003830100591

[95] Reid G, Howard J and Gan BS. Can bacterial interference prevent infection?. Trends Microbiol 2001; 9: 424-28. http://dx.doi.org/10.1016/S0966-842X(01)02132-1
[96] Duffy LC. Interactions mediating bacterial translocation in the immature intestine. J Nutr 2000; 130: 432-36.

[97] Link-Amster H, Rochat $F$, Saudan KY, Mignot $O$ and Aeschlimann JM. Modulation of a specific humoral immune response and changes in intestinal flora mediated through fermented milk intake. FEMS Immunol Med Microbiol 1994; 10: 55-63.

http://dx.doi.org/10.1111/j.1574-695X.1994.tb00011.x

[98] Martin CR and Walker WA. Probiotics: role in pathophysiology and prevention in necrotizing enterocolitis. Semin Perinatol 2008; 32: 127-37. http://dx.doi.org/10.1053/j.semperi.2008.01.006

[99] Cilieborg MS, Boye M and Sangild PT. Bacterial colonization and gut development in preterm neonates. Early Hum Dev 2012; 88: 41-49. http://dx.doi.org/10.1016/j.earlhumdev.2011.12.027

[100] Collado MC, Cernada M, Neu J, Pérez-Martínez G, Gormaz $\mathrm{M}$ and Vento $\mathrm{M}$. Factors influencing gastrointestinal tract and microbiota immune interaction in preterm infants. Pediatric Res 2015; 77: 726-31. http://dx.doi.org/10.1038/pr.2015.54

[101] Deshpande G, Rao S, Keil AD and Patole S. Evidence-based guidelines for use of probiotics in preterm neonates. BMC Med 2011; 9 : 92 .

http://dx.doi.org/10.1186/1741-7015-9-92

[102] DNG Danish National Guideline: probiotics for preterm. 2010; (http://www.rhvejledninger.dk/C1256FF60028FE3A/0/ FADF649DDFCAFF2FC12576AB0030868D).

[103] Sanz Y. Gut microbiota and probiotics in maternal and infant health.Am. J Clin Nutr 2011; 94: 2000-2005. http://dx.doi.org/10.3945/ajcn.110.001172

[104] Schultz M, Gottl C, Young RJ, Iwen P and Vanderhoof JA. Administration of oral probiotic bacteria to pregnant women causes temporary infantile colonization. J Pediat Gastroenterol Nutr 2004; 38: 293-97. http://dx.doi.org/10.1097/00005176-200403000-00012

[105] Martın R, Jimenez E, Heilig H, Fernández L, Marín ML, Zoetendal E.G., Rodríguez JM. Isolation of bifidobacteria from breast milk and assessment of the bifidobacterial population by PCR-denaturing gradient gel electrophoresis and quantitative real-time PCR Appl Environ Microbiol 2009; 75: 965-69.

http://dx.doi.org/10.1128/AEM.02063-08

[106] Boyle RJ, Robins-Browne RM and Tang ML. Probiotic use in clinical practice: what are the risks?. Am J Clin Nutr 2006; 83: 1256-64.

[107] Millar M, Wilks M, Fleming P and Costeloe K. Should the use of probiotics in the preterm be routine?. Arch Dis Child Fetal Neonatal Edu 2012; 97: 70-74. http://dx.doi.org/10.1136/adc.2009.178939

[108] Thomas DW, Greer FR and Committee on Nutrition Probiotics and Prebiotics in Pediatrics. Pediat 2010; 126 : 1217-31.

http://dx.doi.org/10.1542/peds.2010-2548

[109] Wall, R, Ross, RP, Ryan, CA, Hussey S, Murphy B, Fitzgerald GF and Stanton C. Role of gut microbiota in early infant development clinical medicine. Pediatr 2009; 3: 45-54.

[110] Ganguli K and Walker WA. Probiotics in the Prevention of Necrotizing Enterocolitis. J Clin Gastroenterol 2011; 45: 13338.

http://dx.doi.org/10.1097/MCG.0b013e318228b799 